Research note

\title{
Is the Antillean manatee (Trichechus manatus manatus) back in town? Presence of the species at the "Área de Protección de Flora y Fauna Yum Balam”, Quintana Roo, Mexico
}

\author{
¿Está de regreso el manatí antillano (Trichechus manatus manatus)? Presencia de la especie en el \\ "Área de Protección de Flora y Fauna Yum Balam”, Quintana Roo, México \\ José Gerardo Ávila-Canto ${ }^{\mathrm{a}}$, Carolina Velázquez-Mendoza ${ }^{\mathrm{b}}$, Nataly Castelblanco-Martínez ${ }^{\mathrm{c}, \mathrm{d}}$, \\ Carlos Niño-Torres ${ }^{d}$, Fernando Córdova-Tapia ${ }^{\mathrm{e}, *}$ \\ ${ }^{a}$ Manaholchi, S.C., Paseo Kuka mz-171, L-2, 77310 Isla Holbox, Quintana Roo, Mexico \\ ${ }^{\mathrm{b}}$ Facultad de Ciencias, Universidad Nacional Autónoma de México, Facultad de Ciencias, Universidad Nacional Autónoma de México, Circuito Exterior s/n, \\ Ciudad Universitaria, 04510 Ciudad de México, Mexico \\ ${ }^{\mathrm{c}}$ Consejo Nacional de Ciencia y Tecnología, Boulevard Bahía s/n, Del Bosque, 77019 Chetumal, Quintana Roo, Mexico \\ ${ }^{\mathrm{d}}$ Universidad de Quintana Roo, Boulevard Bahía s/n, Del Bosque, 77019 Chetumal, Quintana Roo, Mexico \\ ${ }^{\mathrm{e}}$ Instituto de Biología, Universidad Nacional Autónoma de México, Apartado postal 70-153, 04510 Ciudad de México, Mexico
}

Received 14 March 2017; accepted 26 June 2017

Available online 6 December 2017

\begin{abstract}
The Antillean manatee (Trichechus manatus manatus), considered endangered, is protected at national (Mexico) and international levels. Since Hurricane Gilbert in 1988, sightings of manatees have been rare at Conil Lagoon, located within the natural reserve "Área de Protección de Flora y Fauna Yum Balam”. However, increased reports of sightings from local fishermen and tour guides suggest manatees may be repopulating the lagoon. Here we report 15 sightings of the Antillean manatee from 2011 to 2016 . Group sizes ranged from 1 to 15 individuals and we documented the presence of reproductive groups and mother-calf pairs. The apparent recovery of the species at Conil Lagoon and adjacent areas may be the result of local conservation efforts, or the result of changes in habitat use and distribution of the Caribbean population. A systematic, long-term local monitoring program is necessary to estimate manatee abundance and characterize their distribution in this area.

(C) 2017 Universidad Nacional Autónoma de México, Instituto de Biología. This is an open access article under the CC BY-NC-ND license

(http://creativecommons.org/licenses/by-nc-nd/4.0/).
\end{abstract}

Keywords: Manatee; Trichechus manatus manatus; Natural protected areas; Holbox; Conil Lagoon

\section{Resumen}

El manatí antillano (Trichechus manatus manatus) es una especie en peligro de extinción que se encuentra protegida a nivel nacional (México) e internacional. A partir del paso del huracán Gilberto en 1988, los avistamientos de manatí fueron escasos en la laguna Conil, ubicada dentro del área natural protegida Área de Protección de Flora y Fauna Yum Balam. Sin embargo, el aumento de avistamientos por parte de pescadores locales y guías de turismo sugieren que el manatí podría estar repoblando la laguna. En este trabajo reportamos 15 avistamientos de manatí antillano

\footnotetext{
* Corresponding author.

E-mail address: fernando.cordova.tapia@gmail.com (F. Córdova-Tapia).
}

Peer Review under the responsibility of Universidad Nacional Autónoma de México. 
desde 2010 hasta 2016. El tamaño de los grupos varía desde 1 hasta 15 individuos y documentamos la presencia de grupos reproductivos y pares de madre-cría. La aparente recuperación del manatí en la laguna de Conil y las áreas adyacentes puede deberse a los esfuerzos de conservación a nivel local, o al resultado de cambios en el uso de hábitat y distribución de la población del Caribe. Un programa de monitoreo sistemático a largo plazo es necesario para estimar la abundancia de manatíes y caracterizar su distribución en esta área.

(C) 2017 Universidad Nacional Autónoma de México, Instituto de Biología. Este es un artículo Open Access bajo la licencia CC BY-NC-ND (http://creativecommons.org/licenses/by-nc-nd/4.0/).

Palabras clave: Manatí; Trichechus manatus manatus; Áreas naturales protegidas; Holbox; Laguna Conil

The Antillean manatee (Trichechus manatus manatus) is considered endangered, and therefore is given protection locally in Mexico (Semarnat, 2010) and internationally according to the Red List of Threatened Species (IUCN, 2008) and Appendix I (CITES, 2015). The herbivorous feeding habits of manatees play an important role in the maintenance of ecosystem dynamics, contributing to the trophic cycling and the renewal of organic matter in water bodies (Castelblanco-Martínez, Barba, Schmitter-Soto, Hernández-Arana, \& Morales-Vela, 2012; Rodas-Trejo, Romero, \& Moreno, 2012). Furthermore, the manatee is considered an umbrella species due to its habitat requirements (Rentería, Serrano, \& Sánchez, 2010) and wide home ranges; thus, its health and population size can help orientate conservation-related decisions. Currently, despite extensive protection, the species faces various threats including habitat degradation and loss, hunting, entanglement in fishing nets, and injury from boat collisions (Rodríguez \& Olivera, 2012).

The distribution of this species is fragmented in Mexico; manatees inhabit the states of Tamaulipas (Lazcano-Barrero \& Packard, 1989), Veracruz (Ortega-Argueta, Garza, PortillaOchoa, Keith, \& Cortina-Julio, 2011), Chiapas (Rodas-Trejo, Romero-Berny, \& Estrada, 2008), Campeche (Acevedo-Olvera, Delgado-Estrella, Barreto-Castro, \& Nuñez-Lara, 2015), as well as Yucatán and Quintana Roo (Morales-Vela, Padilla-Saldivar, \& Mignucci-Giannoni, 2003). Decades ago, manatees were reported along the coastal areas of the Gulf of Mexico from the Pánuco River (Veracruz) to the south of Quintana Roo (Morales-Vela, 2010). However, recent research suggests that the species is locally extinct in the north of Veracruz (Serrano, García-Jiménez, \& González-Gándara, 2007) and on the brink of extinction in the rest of this state (Serrano et al., 2017). Assessments of local abundance and density are challenging due to the physical characteristics of the riverine complexes that manatees inhabit within Mexican coastal waters and the tasks they pose for monitoring. Empirical estimates place the remaining manatee population at 1,000-2,000 animals within the entire country (Conanp, 2010); of which approximately 200 individuals are estimated to inhabit Quintana Roo (Morales-Vela \& Padilla, 2001). Genetic studies indicate there are 2 distinct genetic populations in Mexico, 1 along the Caribbean coast and another found in the riverine systems connected to the Gulf of Mexico (Nourisson et al., 2011).

The Conil Lagoon is situated on the northeastern tip of the Yucatán Peninsula within the "Área de Protección de Flora y Fauna Yum Balam”, Quintana Roo, Mexico. The lagoon is $32 \mathrm{~km}$ long with encompassing a total area of $312 \mathrm{~km}^{2}$ (Fig. 1). The bottom is mainly covered by sea grasses and macroalgae, and the depth varies between 0.3 and $3.0 \mathrm{~m}$ (Córdova-Tapia pers. obs.). The warm sub-humid climate results in sporadic rains in the summer. The average annual air temperature ranges from $24^{\circ} \mathrm{C}$ to $25^{\circ} \mathrm{C}$ with a mean precipitation of $1,197 \mathrm{~mm}$ (Inegi, 2014). The Conil Lagoon is thought to be a historically important region for manatees, and was reportedly a major manatee hotspot forty years ago (Conanp, 2011). However, interviews with local people indicate manatee sightings became uncommon after Hurricane Gilbert in 1988 (Morales-Vela et al., 2003). In recent years, local fishermen and tour guides claim an increase in manatee sightings, but a lack of confirmation and associated sighting data make it challenging to confirm these reports. Due to these reports, the civil organization 'Manaholchi' initiated a manatee monitoring program in 2010 in order to document the occurrence of manatees in the area (Ávila-Canto, 2013, 2014). Soon after information was confirmed by aerial surveys (Quintana-Rizzo et al., 2015) and by an observed increase in the annual number of stranded manatees (Ávila-Canto, 2013).

Here we report manatee sightings obtained during sporadic, non-systematic surveys in 2011-2016. The local group 'Manaholchi' conducted surveys in 2010 (November and December), 2011 (January), 2012 (August and December), 2013 (July and September) and 2014 (February and August to December), and additional visits were made in 2016 (June, October and November). Boat-based surveys were conducted using a 25 -ft long vessel with a $60 \mathrm{HP}$ outboard engine at low speeds $\left(<5 \mathrm{~km} \mathrm{~h}^{-1}\right)$, with $3-8$ observers watching a $360^{\circ}$ area around the boat to spot manatees by eye. Surveys areas were randomly selected based on locations of frequent manatee sightings reported by the locals. The presence of the species was confirmed when the manatees exposed their nostrils or other body parts during surface breathing intervals. Overall, 33 surveys with an average duration of $2.4 \pm 2.1 \mathrm{~h}$ were carried out, involving $80.23 \mathrm{~h}$ of total effort (searching and observation). We recorded 15 sightings (Fig. 2), varying from 1 to 15 individuals, including observations of reproductive groups and mother-calf pairs. The animals were observed during feeding and reproductive behaviors, and frequently startled and fled from the research vessel.

The apparent disappearance and return of the Antillean manatee to Conil Lagoon and nearby areas is largely anecdotal, based on reports of local inhabitants of the region. However, caution should be exercised before accepting these claims given no systematic abundance estimates or population monitoring have been conducted in the study area. The causes of the apparent fluctuations in manatee abundance remain unclear, particularly the cause of increases in sighting reports in recent years. 


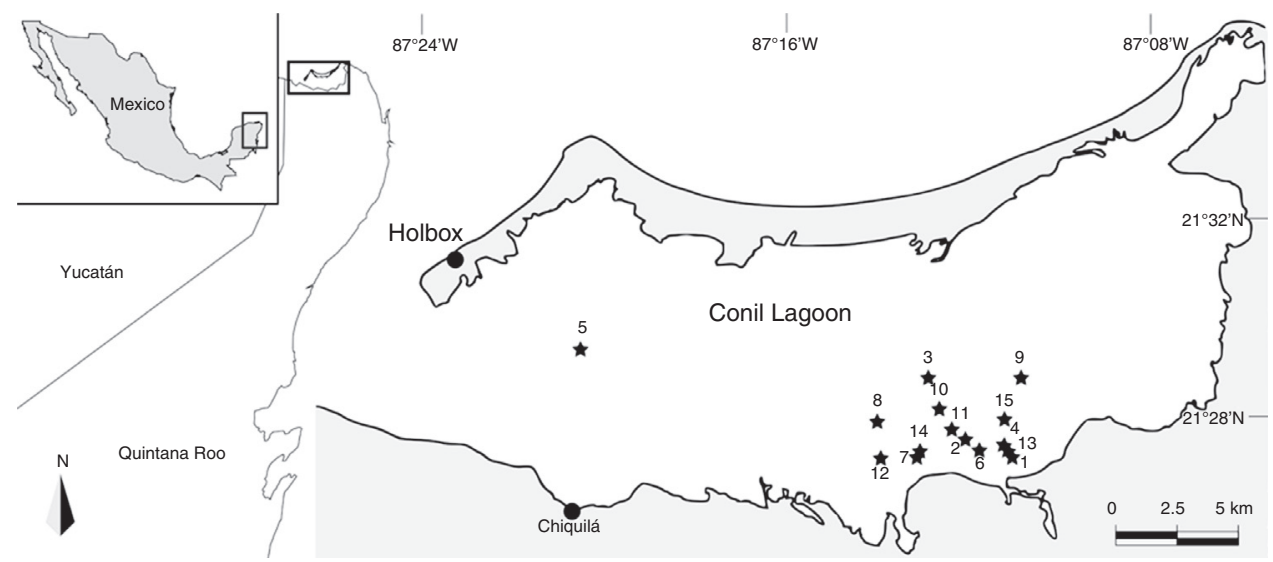

Figure 1. Geographic location of Conil Lagoon. Black stars are the sites where manatees were recorded. Sighting ID [minimum number of individuals] (date): 1 [>3] (25/12/2010); 2 [2] (04/01/2011); 3 [5] (20/01/2011); 4 [15] (20/01/2011); 5 [3*] (11/12/2012); 6 [3†] (15/07/2013); 7 [4] (15/02/2014); 8 [2] (15/02/2014); 9 [6] (15/02/2014); 10 [1] (25/02/2014); 11 [2] (25/02/2014); 12 [2] (01/12/2014); 13 [3] (01/12/2014); 14 [2] (23/06/2016); 15 [2] (31/10/2016). * Mother and 2 calfs; $\uparrow 1$ calf.

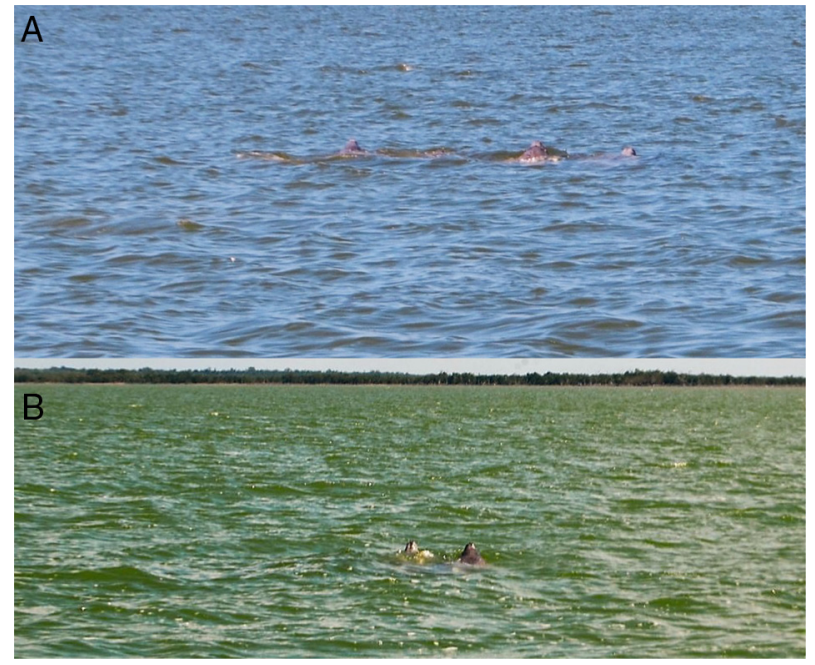

Figure 2. Photographs of manatees at Conil Lagoon during the sightings, 10 (A) in which 5 individuals can be recognized and 11 , (B) with 2 individuals (J. G. Ávila-Canto, 'Manaholchi').

These increases may reflect positive effects of regional conservation efforts (e.g., the creation of the Manatee Sanctuary in the southern part of the state) or increased levels of anthropogenic pressures in nearby areas where the species was previously common. Díaz-Ortiz, Nourisson, and Castelblanco-Martínez (2014) suggested the increasing number of visitors to the highly touristic Rivera Maya (at approx. $70 \mathrm{~km}$ of coastline from Holbox) induced changes in the manatee's habitat use, which reflected in a substantial reduction of manatee sightings in several areas. Manatees may have shifted their distributions north, although more evidence is necessary to support this idea.

The presence of manatee calves and reproductive herds suggests the area may be an important refuge for the species. Therefore, special efforts should be made within the local communities to support environmental education programs, species monitoring and the establishment of areas within the lagoon for manatee conservation. A systematic long-term monitoring program is necessary to assess the abundance and distribution of the species at different spatial and temporal scales, including seasonal variations in habitat use. Other important questions remain unanswered, for example, the level of connectivity with the manatee subpopulations from the Gulf to the Caribbean. Additionally, Holbox Island located in the north of Conil Lagoon is considered to have one of the largest and fastest developing whale and shark watching industries in the world (Ziegler, Dearden, \& Rollins, 2012). Thus, the development of infrastructure and boat traffic may represent a risk for this population in the near future. At least 3 carcasses of manatees have been recovered in Conil Lagoon (Ávila-Canto, 2013) in the last years, possibly a natural component of population size increases; however, signifying manatee mortality must be closely monitored in the area.

This research was partially funded by Programa de Conservación para el Desarrollo Sostenible through Comisión Nacional de Áreas Naturales Protegidas (Conanp/PROCODES/6429/13 and Conanp/PROCODES/5953/2014), the Universidad Nacional Autónoma de México - Programa de Apoyo a Proyectos de Investigación e Innovación Tecnológica (PAPPITIN206114), and the Cetacean Society International. Part of the surveys was conducted in the frame of the Program of Aquatic Megafauna Monitoring in the Mexican Caribbean (PAMMCM) of the Conacyt/University of Quintana Roo. We thank E. A. Ramos and 3 anonymous reviewers for their helpful comments on an early version of the manuscript. The authors thank the unvaluable help of the local people during manatee surveys, particularly the family Ávila Ávila, Leongina Ávila García, Perfecto Ávila Arguelles, Natalio Bacelis, Thomas Daniel Zapata Ancona, Francisco Gasca Cetina, Sandra Lara Santana, Ana Lara Santana and the crew of 'Manaholchi'.

\section{References}

Acevedo-Olvera, G., Delgado-Estrella, A., Barreto-Castro, M. R., \& NuñezLara, E. (2015). Environmental characterization of a fluvial lagoon ecosystem (Pom-Atasta, Campeche, Mexico) as a critical manatee habitat. WIT Transactions on the Built Environment, 168, 407-413. 
Ávila-Canto, J. G. (2013). Monitoreo del manatí y de la laguna Yalahau, Informe Final. Isla Holbox, Quintana Roo: APFFYB-Conanp.

Ávila-Canto, J. G. (2014). Monitoreo y conservación del manatí. Informe Final. Isla Holbox, Quintana Roo: APFFYB-Conanp.

Castelblanco-Martínez, D. N., Barba, E., Schmitter-Soto, J. J., HernándezArana, H. A., \& Morales-Vela, B. (2012). The trophic role of the endangered Caribbean manatee Trichechus manatus in an estuary with low abundance of seagrass. Estuaries and Coasts, 35, 60-77.

CITES (Convención sobre el comercio internacional de especies amenazadas de fauna y flora silvestres). (2015). Apéndices I, II y III.. Retrieved March 11, 2017 from: www.cites.org/sites/default/files/esp/app/2015/ S-Appendices-2015-02-15.pdf

Conanp (Comisión Nacional de Áreas Naturales Protegidas). (2010). Programa de acción para la conservación de la especie: manatí (Trichechus manatus manatus). Conanp: Ciudad de México.

Conanp (Comisión Nacional de Áreas Naturales Protegidas). (2011). Borrador del programa de manejo del Área de Protección de Flora y Fauna Yum Balam. Isla Holbox, Quintana Roo: APFFYB-Conanp.

Díaz-Ortíz, M., Nourisson, C., \& Castelblanco-Martínez, D. N. (2014). Presence and persistence of the West Indian manatee (Trichechus manatus manatus) after 15 years in the north of Quintana Roo, Mexico. Sirenews, 61, 7.

Inegi (Instituto Nacional de Estadística y Geografía). (2014). Anuario estadístico y geográfico de Quintana Roo 2014. México, DF: Inegi.

IUCN (International Union for Conservation of Nature). (2008). The IUCN red list of threatened species, Version 3.1.. Retrieved March 11, 2017 from: www.iucnredlist.org

Lazcano-Barrero, M., \& Packard, J. M. (1989). The occurrence of manatees (Trichechus manatus) in Tamaulipas, México. Marine Mammal Science, 5, 202-205

Morales-Vela, B. (2010). Conservación del manatí y su situación en México. In J. Carabias, J. Saruhkán, J. de la Maza, \& C. Galindo (Eds.), Patrimonio natural de México, cien casos de éxito (pp. 70-71). México, D.F.: Conabio.

Morales-Vela, B., \& Padilla, J. (2001). Los manatíes en Quintana Roo. Ecofronteras, 5, 7-9.

Morales-Vela, B., Padilla-Saldivar, J., \& Mignucci-Giannoni, A. (2003). Status of the manatee (Trichechus manatus) along the northern and western coasts of the Yucatán Peninsula, Mexico. Caribbean Journal of Science, 39, 42-49.

Nourisson, C., Morales-Vela, B., Padilla-Saldívar, J., Tucker, K., Clark, A., Olivera-Gómez, L., et al. (2011). Evidence of two genetic clusters of manatees with low genetic diversity in Mexico and implications for their conservation. Genetica, 7, 833-842.
Ortega-Argueta, A., Garza, S., Portilla-Ochoa, E., Keith, E. O., \& Cortina-Julio, B. (2011). Distribution, status and conservation of the Antillean manatee (Trichechus manatus manatus) in Veracruz, Mexico. In 19th Biennial Conference on the Biology of Marine Mammals, Tampa, Florida, November 26, 2011.

Quintana-Rizzo, E., Casteblanco-Martínez, N., Edwards, H., Morales-Vela, B., Ubeda, A., \& Walker, Z. (2015). First regional aerial survey of Antillean manatees (Trichechus manatus manatus) in the Mexico-Belize-Guatemala region of Central America. In 20th Biennial Conference on the Biology of Marine Mammals, San Francisco, California, December 13, 2015.

Rentería, D., Serrano, A., \& Sánchez, G. (2010). El manatí (Trichechus manatus manatus Linnaeus, 1758) (Sirenia) una especie sombrilla, para el Sistema Lagunar de Alvarado, Veracruz. Cuadernos de Biodiversidad, 33, 16-23.

Rodas-Trejo, J., Romero-Berny, E. I., \& Estrada, A. (2008). Distribution and conservation of the West Indian manatee (Trichechus manatus manatus) in the Catazajá wetlands of northeast Chiapas, México. Tropical Conservation Science, 1, 321-333.

Rodas-Trejo, J., Romero, E., \& Moreno, E. (2012). Conocimiento biológico, usos y actitudes hacia el manatí (Trichechus manatus manatus) por los pobladores del sistema de humedales Catazajá-La Libertad, Chiapas, México. Lacandonia, 6, 91-99.

Rodríguez, N., \& Olivera, L. (2012). Situación de una población aislada de manatíes Trichechus manatus manatus (Mammalia: Sirenia: Trichechidae) y conocimiento de la gente, en una laguna urbana, en Tabasco, México. Universidad y Ciencia, 28, 15-26.

Semarnat (Secretaría del Medio Ambiente y Recursos Naturales). (2010). Norma Oficial Mexicana NOM-059-SEMARNAT-2010, Protección ambiental - Especies nativas de México de flora y fauna silvestres - Categorías de riesgo y especificaciones para su inclusión, exclusión o cambio - Lista de especies en riesgo. Segunda Sección, México: Diario Oficial de la Federación, 30 de diciembre de 2010.

Serrano, A., Daniel-Rentería, I., Hernández-Cabrera, T., Sánchez-Rojas, G., Cuervo-López, L., \& Basáñez-Muñoz, A. (2017). Is the West Indian manatee (Trichechus manatus) at the brink of extinction in the state of Veracruz, Mexico? Aquatic Mammals, 43, 201-207.

Serrano, A., García-Jiménez, A., \& González-Gándara, C. (2007). Has the manatee (Trichechus manatus) disappeared from the northern coast of the state of Veracruz Mexico? Latin American Journal of Aquatic Mammal, 6, 109-112.

Ziegler, J., Dearden, P., \& Rollins, R. (2012). But are tourists satisfied? Importance-performance analysis of the whale shark tourism industry on Isla Holbox, Mexico. Tourism Management, 33, 692-701. 